\title{
Z prac nad prawnym uregulowaniem ochrony i opieki nad grobami wojennymi w II Rzeczypospolitej
}

\section{WPROWADZENIE}

Ze względu na swą masowość i tragizm okoliczności nagłej śmierci grobownictwo wojenne ${ }^{1}$ od zawsze miało status szczególny wśród zagadnień związanych z organizacją cmentarzy. Choć problem pozostałych na polach bitew zwłok żołnierzy istniał od pierwszych konfliktów zbrojnych, przez wieki nie był traktowany jako istotny, ani w znaczeniu prawnym, ani faktycznych działań. Poległych grzebano najczęściej w masowych nieoznaczonych grobach na polach bitew albo zostawiano na miejscu śmierci, często na pastwę szabrowników i dzikich zwierząt. Nie prowadzono też żadnych spisów poległych, a pamięć o ofiarach wojen ginęła wraz z ostatnią znającą je osobą.

$\mathrm{Z}$ czasem, wraz z rozwojem humanizmu, prawa międzynarodowego i standardów sanitarnych, podejmowano działania na rzecz zapewnienia poległym godnego miejsca spoczynku i upamiętnienia. Przełom w tym względzie stanowiła konwencja genewska z 22 sierpnia 1864 r., a także jej następczyni z 6 lipca 1906 r., które traktowały przede wszystkim o chorych i rannych ${ }^{2}$. Można jednak znaleźć w nich również regulacje dotyczące zwłok ofiar konfliktów zbrojnych. Konwencja z 1906 r. w art. 3 zobowiązywała zajmującego pole walki m.in. do wyszukania i zabezpieczenia zabitych przed ograbieniem i złym traktowaniem, natomiast

\footnotetext{
${ }^{1}$ Termin powszechnie używany w okresie międzywojennym; odnosił się do wszelkich zagadnień związanych z ochroną i opieką nad grobami i cmentarzami wojennymi.

${ }^{2}$ Do tej drugiej Polska przystąpiła na mocy ustawy z dnia 23 lipca 1926 r. o zatwierdzeniu zgłoszonego przez rząd Polski w dniu 28 czerwca 1919 r. przystąpienia Rzeczypospolitej do międzynarodowej konwencji o polepszeniu losu chorych i rannych w armjach czynnych, podpisanej w Genewie dnia 6 lipca 1906 r. (Dz. U. 1926 nr 83, poz. 462).
} 
przed pogrzebem lub spaleniem ich ciała miały być dokładnie zbadane ${ }^{3}$. Artykuł 4 nakazywał każdej stronie przesyłanie właściwym władzom państw lub armiom oznak lub dowodów legitymacyjnych poległych, a także znalezionych przy nich przedmiotów osobistego użytku, papierów wartościowych i listów. Do tego należało przekazywać listy zgonów osób rannych i chorych pozostających pod opieką drugiej strony konfliktu.

Będąca rozszerzeniem tych uregulowań konwencja genewska o polepszeniu losu rannych i chorych z 27 lipca 1929 r. doprecyzowała powyższe postanowienia $^{4}$. W art. 4 przewidywała badanie zwłok przez lekarzy celem stwierdzenia śmierci, ustalenia tożsamości i podania jej do wiadomości's Strony konwencji miały także czuwać, aby zabici byli pochowani z czcią, a ich groby były ochraniane i zawsze mogły być odszukane. $Z$ rozpoczęciem kroków nieprzyjacielskich strony miały także ustanowić zarząd grobów, który gromadząc informacje, miał umożliwiać późniejszą ekshumację i planowe rozmieszczenie grobów. Po ustaniu działań wojennych strony miały przekazywać sobie spisy zabitych oraz spisy grobów. Oprócz tego konwencja genewska o jeńcach wojennych z 27 lipca 1929 r. ${ }^{6} \mathrm{w}$ art. 76 nakazywała grzebanie z czcią jeńców wojennych znajdujących się w niewoli, a także należyte oznaczenie i utrzymanie ich grobów $^{7}$. Z kolei traktująca także o jeńcach wojennych haska konwencja dotycząca praw i zwyczajów wojny lądowej z 18 października 1907 r. ${ }^{8}$ w art. 19 nakazy-

${ }^{3}$ Polski tekst urzędowy konwencji opublikowano zarządzeniem Prezydenta Rzeczypospolitej z dnia 26 stycznia 1927 r. w sprawie opublikowania Międzynarodowej Konwencji Genewskiej z dnia 6 lipca 1906 r. o polepszeniu losu rannych i chorych w armjach czynnych (Dz. U. nr 28, poz. 225).

${ }^{4}$ W Polsce ratyfikowana ustawą z dnia 28 stycznia 1932 r. w sprawie ratyfikacji konwencji o polepszeniu losu rannych i chorych w armjach czynnych, podpisanej w Genewie dnia 27 lipca 1929 r. (Dz. U. nr 24, poz. 179).

${ }^{5}$ Konwencja Genewska o polepszeniu losu chorych i rannych w armjach czynnych, podpisana dnia 27 lipca 1929 r. (ratyfikowana zgodnie z ustawą z dnia 28 stycznia 1932 r.). (Dz. U. 1932, nr 103, poz. 864).

${ }^{6}$ W Polsce ratyfikowana ustawą z dnia 18 lutego 1932 r. w sprawie ratyfikacji konwencji, dotyczącej traktowania jeńców wojennych, podpisanej w Genewie dnia 27 lipca 1929 r. (Dz. U. nr 31, poz. 318).

${ }^{7}$ Konwencja dotycząca traktowania jeńców wojennych, podpisana w Genewie dnia 27 lipca 1929 r. (ratyfikowana zgodnie z ustawą z dnia 18 lutego 1932 r.). (Dz. U. 1932, nr 103, poz. 866).

${ }^{8}$ W Polsce ratyfikowana ustawą z dnia 1 kwietnia 1924 r. w przedmiocie przystąpienia Rzeczypospolitej Polskiej do międzynarodowej konwencji, dotyczącej praw i zwyczajów wojny lądowej, podpisanej w Hadze dnia 18 października 1907 r. wraz z odnośnym regulaminem (Dz. U. nr 37, poz. 395). Oświadczenie rządowe z dnia 20 stycznia 1927 r. w sprawie przystąpienia Rzeczypospolitej Polskiej do Międzynarodowej Konwencji, dotyczącej praw i zwyczajów wojny lądowej, podpisanej wraz z odnośnym regulaminem w Hadze dnia 18 października 1907 r. (Dz. U. nr 21, poz. 160). 
wała grzebanie jeńców według zasad grzebania wojskowych, z uwzględnieniem ich rangi i tytułu?.

Tego typu umowy międzynarodowe, abstrahując od ich trwałości i rzeczywistego przestrzegania, regulowały jedynie powinności stron trwającego konfliktu zbrojnego w stosunku do poległych strony przeciwnej, nie odnosiły się do istniejących grobów i cmentarzy wojennych, a przede wszystkim do własnych mogił żołnierzy. Działania wobec nich zależały więc od zarządzeń i legislacji poszczególnych państw.

Odrodzone po latach zaborów państwo polskie odziedziczyło prawny i faktyczny stan grobownictwa wojennego ustanowiony przez zaborców. Sprawiało to, że na poszczególnych obszarach Rzeczypospolitej był on zależny nie tylko od przeprowadzonych w danym miejscu działań wojennych, ale także od tego, która ze stron zarządzała tym terenem $\mathrm{w}$ danym czasie $^{10}$. Sytuacja była tym poważniejsza, że na terytorium Polski znajdowało się mnóstwo niezewidencjonowanych i pozostawionych bez opieki pojedynczych i zbiorowych mogił wojennych ofiar właśnie zakończonej Wielkiej Wojny.

\section{DYSKUSJE NAD SYSTEMOWĄ ORGANIZACJĄ OPIEKI NAD GROBAMI WOJENNYMI}

Dyskusje o zorganizowaniu systemowej opieki nad grobami wojennymi rozpoczęto dość szybko po powstaniu niepodległego państwa polskiego. Początkowo największą kwestią sporną było wyznaczenie odpowiedzialnego za tę sprawę resortu. Dnia 3 marca 1919 r. za niewłaściwe w tej kwestii uznało się Ministerstwo Wyznań Religijnych i Oświecenia Publicznego (MWRiOP) ${ }^{11}$, toteż 15 maja tego samego roku zorganizowano w Ministerstwie Spraw Wojskowych (MSWojsk) międzyministerialną konferencję $\mathrm{w}$ tej sprawie. Uczestniczyli $\mathrm{w}$ niej przedstawiciele Ministerstwa Spraw Wewnętrznych (MSW, radcy ministerialni Władysław Weissbrod i Atenogenes Pawlikiewicz), Ministerstwa Zdrowia Publicznego

${ }^{9}$ Konwencja dotycząca praw i zwyczajów wojny lądowej (Dz. U. 1927, nr 21, poz. 161).

${ }^{10}$ Więcej o grobownictwie wojennym krajów zaborczych w czasie I wojny światowej: J. Schubert, Organizacja grobownictwa wojennego w Monarchii Austro-Wegierskiej. Dziewiaty wydziat grobów wojennych (Kriegsgräber-Abteilung) przy Ministerstwie Wojny - powstanie i działalność w latach 1915-1918, „Czasopismo Techniczne. Architektura” 2009, 3-A, z. 13, s. 169-200; J. Schubert, Stużby grobownicze armii austro-węgierskiej, niemieckiej i rosyjskiej w czasie I wojny światowej (1915-1918), „Czasopismo Techniczne. Architektura” 2011, 5-A, z. 16, s. 201-223.

${ }^{11}$ Archiwum Akt Nowych, Zespół: Ministerstwo Wyznań Religijnych i Oświecenia Publicznego [dalej: AAN, MWRiOP], sygn. 659: Cmentarze - rozporządzenia, instrukcje o zakładaniu cmentarzy, taryfach opłat za obrzędy pogrzebowe, wywłaszczaniu pod cmentarze itp. oraz dotyczące cmentarzy w wielu parafiach [dalej: sygn. 659], k. 406, 408-409. 
(MZP, radca inż. Matuszewski), Ministerstwa Sztuki i Kultury (MSiK, kierownik Wydziału Architektury i Opieki nad Krajobrazem Juliusz Kłos), Konsystorza Polowego (ks. Tadeusz Jachimowski) oraz Inspekcji Grobów Wojennych w Krakowie (architekt, por. Wąs) ${ }^{12}$. Zaproszono także przedstawicieli Ministerstwa Rolnictwa i Dóbr Państwowych (MRiDP), Ministerstwa Robót Publicznych (MRP) i Ministerstwa Skarbu (MSk). Najszerszą reprezentację wystawiło MSWojsk w osobie szefa Departamentu Technicznego inż. gen. ppor. Władysława Koziełł-Poklewskiego, szefa Sekcji Budownictwa Wojskowego inż. ppłk Grzegorza Stefanowicza oraz inżynierów Sekcji Budownictwa Czesława Gajzlera, Tadeusza Grzywińskiego, Kazimierza Macha, Wernera, Sadowskiego i Brauna, a także przedstawiciela Departamentu Sanitarnego kpt. dra Stępniewskiego.

Porucznik Wąs przedstawił dotychczasową organizację grobów wojennych w Galicji prowadzoną przez władze austriackie. Wyodrębniono w niej trzy działy: ewidencyjny (rozpoznawanie poległych bez względu na przynależność wojskową i narodowościową), budownictwa (projektowanie cmentarzy, grupowanie grobów, ekshumacje, przewóz zwłok) i biuro prezydialne. Efektem było utworzenie w Galicji Zachodniej 407 cmentarzy (60 nie było jeszcze ukończonych) zawierających 160 tysięcy grobów i ustalenie ponad 50\% nazwisk poległych ${ }^{13}$. Krakowski Oddział Grobów miał wielu specjalistów inżynierów architektów, Wąs ubolewał jednak, że ,żywioł polski nie miał wpływu” na główny kształt prac, przez co elementy polskiej architektury i polskiej estetyki miały być zaniedbane. Niezbędne środki pieniężne pochodziły z dwóch źródeł: ofiarności publicznej (fundusz wyniósł ponad milion koron, oprócz tego składano dary w naturze w formie materiałów budowlanych) oraz funduszu ze Skarbu Państwa (początkowo 10 koron na urządzenie jednego grobu, później 20 koron, ogólny koszt wybudowania wszystkich cmentarzy wyniósł ok. 10 milionów koron, nie licząc kosztów utrzymania zarządu, prac żołnierzy i prac jeńców). Wraz z ustąpieniem wojsk austriackich 1 listopada 1918 r. zarząd nad cmentarzami wojennymi przeszedł w ręce Wojska Polskiego wraz z całym inwentarzem i funduszami, które wynosiły ok. 625 tysięcy koron ${ }^{14}$. Opiekę nad nimi powierzono wojskowej inspekcji grobów, która w czasie konferencji miała już nie rozporządzać żadnymi funduszami celowymi.

Przewodniczący posiedzenia, gen. Koziełł-Poklewski, podjął temat uzyskania kredytów niezbędnych do uporządkowania i późniejszej konserwacji cmentarzy ${ }^{15}$, a ppłk Stefanowicz zaproponował, aby sprawę tę przedstawić w formie pisemnego protokołu Radzie Ministrów z wnioskiem o ich pozyskanie i utworzenie

\footnotetext{
12 AAN, MWRiOP, sygn. 659, k. 410.

13 Ibidem, k. 412-413.

14 Ibidem, k. 414.

15 Ibidem.
} 
specjalnego urzędu do uregulowania kwestii grobów wojskowych, co przyjęto bez dyskusji. Przedstawiciel Ministerstwa Robót Publicznych ostrzegał przed podążaniem śladem państw zachodnich, które budowały kosztowne, monumentalne nekropolie i pomniki. Z uwagi na oszczędności postulował działanie na skromniejszą skalę i przekazanie opieki nad grobami samorządom, przy zapewnieniu im odpowiednich kredytów na ten cel ${ }^{16}$. Takiej propozycji sprzeciwił się reprezentant Sekcji Samorządowej MSW ze względu na nadmierne obciążenie ciał samorządowych różnymi innymi sprawami. Przedstawiciel Ministerstwa Sztuki i Kultury zgłosił pomysł podzielenia wydatków na jednorazowe, które miałyby być ograniczone do minimum, oraz stałe, które byłyby pokrywane z utworzonego na ten cel funduszu ${ }^{17}$. Deklarował wsparcie MSiK, ale wyłącznie w zakresie estetyki krajobrazu. Konsystorz Polowy także zawęził pomoc kurii biskupiej do sprawowania obowiązków liturgicznych wobec poległych ${ }^{18}$.

Złożono wniosek, aby sprawę przekazać MSWojsk, ppłk Stefanowicz wyjaśnił jednak, że MSWojsk natrafiłoby na ogromne trudności w tej kwestii ze względu na brak stałego kontaktu z władzami samorządowymi. Przewodniczący komisji zaproponował więc przeniesienie sprawy na MRP ze względu na jego „szeroko rozgałęzione agendy po powiatach"19. Współudział przy organizacji urzędu miały mieć MSWojsk, MSW, MSiK, MZP, MRiDP oraz przedstawiciel Wojskowej Kurii Biskupiej bądź MWRiOP ${ }^{20}$. Na koniec spotkania przedstawiciel MSW złożył wniosek o budowę domków mieszkalnych przy cmentarzach, które miałyby być przekazane inwalidom wojennym mającym opiekować się grobami wojennymi.

Wkrótce po posiedzeniu komisji MSWojsk zwróciło się z oficjalną prośbą do MRP o zorganizowanie i podjęcie opieki nad grobami poległych żołnierzy ${ }^{21}$. MRP odpowiedziało 17 lipca, że nie może się tym zająć z powodu przekazania mu „całego szeregu spraw pierwszorzędnego dla Kraju znaczenia”22.

Sprawa grobów wojennych przestała być kwestią wewnętrzną, gdyż wraz $\mathrm{z}$ ratyfikowaniem traktatu wersalskiego ${ }^{23}$ państwo polskie zobowiązało się do poszanowania i utrzymywania grobów żołnierzy i marynarzy pozostałych sygnatariuszy traktatu pochowanych na jego terytorium ${ }^{24}$. Artykuł 225 nakazywał powszechne uznanie komisji wyznaczonej przez którykolwiek z rządów sprzy-

${ }^{16}$ Ibidem, k. 415.

17 Ibidem.

18 Ibidem, k. 416-417.

${ }^{19}$ Ibidem, k. 416.

${ }^{20}$ Ibidem, k. 417.

${ }^{21}$ Ibidem, k. 409.

22 Ibidem, k. 407-408.

${ }^{23}$ Ustawa z dnia 31 lipca 1919 r. o ratyfikacji traktatu pokoju (Dz. U. 1920, nr 35, poz. 199).

${ }^{24}$ Traktat pokoju między mocarstwami sprzymierzonemi i skojarzonemi i Niemcami, podpisany w Wersalu dnia 28 czerwca 1919 r. (Dz. U. 1920, nr 35, poz. 200). 
mierzonych i stowarzyszonych do stwierdzenia tożsamości, spisywania, utrzymywania lub wznoszenia odpowiednich pomników na grobach żołnierzy i marynarzy, a także ułatwienia przeniesień szczątków do ich krajów ojczystych. Artykuł 226 rozszerzał powyższe obowiązki i uprawnienia w stosunku do grobów jeńców wojennych i osób internowanych, zawierał również zobowiązanie państw podpisujących traktat do wzajemnego dostarczenia sobie pełnego wykazu zmarłych wraz ze wszystkimi objaśnieniami przydatnymi do stwierdzenia ich tożsamości oraz wszelkich wskazówek co do liczby i miejsca grobów wszystkich zmarłych pochowanych bez stwierdzenia tożsamości. Analogiczne przepisy znalazły się także w traktacie z Saint-Germain-en-Laye podpisanym przez państwa Ententy i Austrię (art. 171 i 172), a ratyfikowanym przez Polskę w 1924 r. ${ }^{25}$

Przepisy o grobach wojennych znalazły się także w traktacie ryskim podpisanym w 1921 r. między Polską a sowiecką Rosją i sowiecką Ukrainąa ${ }^{26}$. W pkt 3 art. IX sygnatariusze zobowiązali się do poszanowania i odpowiedniego utrzymywania znajdujących się na ich terytoriach grobów jeńców wojennych, zmarłych w niewoli, żołnierzy, oficerów i innych wojskowych poległych na polach bitew, a także grobów jeńców cywilnych, zakładników, osób internowanych, wygnańców, uchodźców i emigrantów. Na przyszłość zastrzeżono również wyrażanie zgody na stawianie na takich grobach pomników oraz na ekshumację i przewożenie szczątków do krajów ojczystych. W pkt 4 art. IX zobowiązano się do wzajemnego dostarczania aktów zejścia wyżej wymienionych, a także podawania do wiadomości liczby i miejsca pochowania wszystkich osób zmarłych bez stwierdzenia ich tożsamości.

Patowa sytuacja związana $\mathrm{z}$ odmową MRP zaowocowała zwołaniem kolejnej konferencji, która odbyła się 20 sierpnia 1919 r. z udziałem wiceprezes Polskiego Czerwonego Krzyża Heleny Bisping, zastępcy komisarza rządowego ds. PCK Henryka Wysockiego i przedstawicieli MSW (Rutkowskiego), MZP (dra Wacława Stefańskiego) i MSWojsk (mjra Sztabu Generalnego Zygmunta Dzwonkowskiego ${ }^{27}$. Rutkowski wyraził zaniepokojenie brakiem zaproszenia dla MWRiOP, któremu dekretem Rady Regencyjnej z dnia 3 stycznia 1918 r. prze-

${ }^{25}$ Traktat pokoju pomiędzy Mocarstwami Sprzymierzonemi i Stowarzyszonemi z jednej strony a Austrją z drugiej, protokół o warunkach wykonania pewnych postanowień tego Traktatu, deklaracja, dotycząca szkód wskutek zatopienia okrętów i ładunków przez austrjackie siły morskie podczas działań wojennych, protokół podpisania, porozumienie pomiędzy Mocarstwami Sprzymierzonemi i Stowarzyszonemi w sprawie udziału w wydatkach, związanych z oswobodzeniem terytorjów byłej Monarchji austrjacko-węgierskiej, porozumienie pomiędzy Mocarstwami Sprzymierzonemi i Stowarzyszonemi w sprawie rozrachunku odszkodowań, o ile to dotyczy Włoch, podpisane w St.-Germain-en-Laye dnia 10 września 1919 r. (Dz. U. 1925, nr 17 poz. 114).

${ }^{26}$ Traktat pokoju między Polską a Rosją i Ukrainą podpisany w Rydze dnia 18 marca $1921 \mathrm{r}$. (Dz. U. nr 49, poz. 300).

${ }^{27}$ AAN, MWRiOP, sygn. 659, k. 426. 
kazano w ówczesnym Królestwie Polskim sprawy gospodarki nad grobami wojennymi ${ }^{28}$. MSWojsk zmieniło koncepcję, gdyż mjr Dzwonkowski oświadczył, że jego ministerstwo uważa sprawę grobów wojennych za swoją kompetencję i podejmie się utworzenia stosownego urzędu do opieki nad tymi obiektami ${ }^{29}$. Według podanych przez niego informacji liczbę pochowanych żołnierzy szacowano na 155 tysięcy na terenach okupacji austriackiej i 200-300 tysięcy w byłym Generalnym Gubernatorstwie Warszawskim ${ }^{30}$. Raportował on także o przejęciu przez polskie władze wojskowe urzędów ds. grobów wojennych zorganizowanych przez okupantów oraz o prowadzonej organizacji ewidencji i statystyki grobów.

Wiceprezes PCK uznała, że oparcie strony finansowej na ofiarności publicznej było w tamtym momencie nierealne, gdyż miała być ona ,wyzyskana na cele żywych żołnierzy, przed którymi umarli muszą na razie ustąpić”31. Zaproponowała więc tymczasowe ograniczenie się do prostszego zabezpieczenia grobów. $\mathrm{Z}$ takim postawieniem sprawy polemizował Wysocki, który uznał, że należyta cześć i szacunek dla poległego żołnierza miały mieć wpływ na morale wojskowe ${ }^{32}$. Podobne zdanie wyraził Rutkowski, który podkreślał potrzebę wywłaszczenia gruntów prywatnych użytkowanych na grzebanie poległych.

Bisping zastanawiała się także nad możliwością ustanowienia specjalnego niewielkiego podatku celowego ${ }^{33}$. Wysocki odrzucił taką możliwość ze względu na wciąż nieuregulowany system podatkowy w kraju. Major Dzwonkowski deklarował, że MSWojsk jest w stanie zająć się ekshumacją, scalaniem oraz prymitywnym zabezpieczeniem i ogrodzeniem cmentarzy oraz ewidencją poległych i ich grobów, natomiast „otoczenie ich opieką artystyczną i nadanie im charakteru hołdu dla poległych" miałoby stanowić powinność społeczną. Dlatego postulował wezwanie MSWojsk do utworzenia stosownego urzędu opieki nad grobami wojennymi oraz PCK do ustanowienia w swoich ramach specjalnej jednostki wspierającej go organizacyjnie ${ }^{34}$.

${ }^{28}$ Kompetencje w zakresie grobów wojennych nie wynikały jednak z treści przywołanego dekretu, gdyż jego art. 26 brzmiał: „Do Ministra Oświaty i Wyznań należy zarząd szkolnictwa wszelkich stopni i typów, opieka nad nauką, literaturą i sztuką, nad archiwami, bibljotekami publicznemi, czytelniami, muzeami i teatrami oraz wykonywanie wszelkich praw i opieki Państwa w sprawach wyznaniowych”. Dekret Rady Regencyjnej o tymczasowej organizacji Władz Naczelnych w Królestwie Polskiem (Dz. U. 1918, nr 1, poz. 1). Taka interpretacja Rutkowskiego wynikała najprawdopodobniej z szerokiego pojmowania spraw wyznaniowych. Więcej o wspomnianym dekrecie w odniesieniu do MWRiOP: P. Leszczyński, Centralna administracja wyznaniowa II RP. Ministerstwo Wyznań Religijnych i Oświecenia Publicznego, Warszawa 2006, s. 154-158.

29 AAN, MWRiOP, sygn. 659, k. 422.

${ }^{30}$ Ibidem, k. 427.

${ }^{31}$ Ibidem, k. 428.

32 Ibidem.

33 Ibidem, k. 429.

34 Ibidem, k. 430. 
Doktor Stefański polecił zastanowić się nad możliwością spopielenia części zwłok w krematoriach ${ }^{35}$, a także zwrócił uwagę na międzynarodowy charakter sprawy z racji znajdujących się na terenie Polski pogrzebanych zwłok żołnierzy obcej narodowości ${ }^{36}$. Należyta opieka nad ich grobami miałaby być wizytówką Polaków jako narodu kulturalnego, stanowiłaby też dla innych państw argument przemawiający za dbałością o polskie miejsca pochówku znajdujące się w ich granicach. Na koniec obrad wiceprezes Bisping zaproponowała utworzenie Komitetu Grobów Wojennych pod egidą PCK, który stanowiłby platformę współpracy dla wszystkich stron zainteresowanych tą sprawą.

\section{ORGANIZACJA GROBOWNICTWA WOJENNEGO W PIERWSZYCH LATACH NIEDPODLEGŁOŚCI}

Na skutek tych ustaleń w listopadzie 1919 r. utworzono przy każdym wojskowym okręgu generalnym Urząd Opieki nad Grobami Wojennymi ${ }^{37}$. Pod względem wojskowo-administracyjnym każdy z nich miał być zależny od szefa sztabu, a pod względem gospodarczym - od kompanii sztabowej. Miał zajmować się m.in. dokładną ewidencją cmentarzy i grobów wojennych, zakładaniem katastrów dla takich grobów, informowaniem opinii publicznej o sprawach grobów wojennych, propagowaniem idei opieki nad grobami wojennymi, sprawami ekshumacji i przewozu zwłok poległych czy kontrolą prac budowlanych na cmentarzach wojennych. Przy Zarządzie Budownictwa Wojskowego pozostawiono wszelkie budowy, remonty i upiększanie grobów wojennych, sprawy cmentarno-gruntowe i inne związane z tym czynności, jak wykonywanie planów, szkiców czy kosztorysów $^{38}$. Pod taką organizacją podpisali się szef Sekcji Religijno-Wyznaniowej MSWojsk mjr Bronisław Pieracki i wiceminister spraw wojskowych gen. ppor. Kazimierz Sosnkowski.

Na centralnym szczeblu ministerialnym to właśnie jednostka kierowana przez Pierackiego była odpowiedzialna za groby wojenne. Istniejąca od czerwca $1919 \mathrm{r}$. Sekcja Religijno-Wyznaniowa obejmowała służbę wszystkich wyznań nieobjętych uprawnieniami rzymskokatolickiej Kurii Biskupiej, weszła w skład Departamentu I Mobilizacyjno-Organizacyjnego MSWojsk ${ }^{39}$. W marcu 1920 r. została $\mathrm{z}$ niego wydzielona jako organ pracy podległy bezpośrednio ministrowi spraw

${ }^{35}$ Ibidem.

${ }^{36}$ Ibidem, k. 431.

${ }^{37}$ Ibidem, k. 403. W dokumencie źródłowym określony jako Urząd Opieki nad Grobami Wojskowymi.

${ }^{38}$ Ibidem, k. 405.

${ }^{39}$ K. Szczygielski, Niekatolickie duszpasterstwo wojskowe w Polsce XX wieku [w:] A. Lityński, P. Fiedorczyk (red.), Wielokulturowość polskiego pogranicza: ludzie - idee - prawo. Materia- 
wojskowych i przemianowana na Sekcję Wyznań Obcych MSWojsk, a następnie na Sekcję Wyznań Niekatolickich i Opieki nad Grobami Wojennymi. Jedną z jej dziewięciu komórek organizacyjnych był Główny Urząd Opieki nad Grobami Wojennymi. Razem z odpowiedzialnym za techniczne kwestie budowlane Departamentem Budownictwa Wojskowego koordynował prace poszczególnych okręgowych urzędów opieki nad grobami wojennymi ${ }^{40}$.

Dnia 7 lutego 1920 r. ustalono zakres działania Biura Informacyjnego Czerwonego Krzyża (BICK) ${ }^{41}$. Choć nie zamieszczono w nim jednoznacznego odniesienia do grobów wojennych, to jednym z zadań BICK miało być udzielanie informacji o poległych. W zakresie tych informacji zapewne mieściły się dane o miejscu pochówku, o ile oczywiście było ono znane. Należy jednak zaznaczyć, że udzielanie tych informacji miało dotyczyć jedynie oficerów, urzędników i żołnierzy wojsk polskich, a więc obowiązek ten nie dotyczył grobów powstałych w czasie niedawno zakończonej Wielkiej Wojny. W maju 1921 r. do przekazywania danych do BICK zobligowano także Sekcję Wyznań Niekatolickich i Opieki nad Grobami Wojennymi ${ }^{42}$.

Trwające działania wojenne podczas wojny polsko-bolszewickiej nie pozostały bez echa w kwestii bieżącej organizacji grobownictwa wojennego. Dnia 26 kwietnia 1920 r. nakazano pozafrontowym księżom kapelanom nadsyłanie urzędom opieki nad grobami wojennymi raz na miesiąc wykazów grobów wojskowych z miejscowości, w których pracowali ${ }^{43}$. Z kolei księża kapelani frontowi mieli nadsyłać takie wykazy do generalnego dziekana przy Naczelnym Dowództwie, który miał je przesyłać do urzędów opieki nad grobami wojennymi tworzonych na zajętych terenach. W wykazie należało zamieścić imię i nazwisko poległego, szarżę, pułk, datę śmierci i pogrzebu, miejscowość położenia cmentarza, określenie charakteru cmentarza (parafialny/wojskowy), opis miejsca założenia grobu bądź cmentarza oraz numer grobu. W październiku 1920 r. zezwolono na przewóz zwłok polskich żołnierzy koleją, a podania w tej sprawie należało kierować do Sekcji Wyznań Niekatolickich i Opieki nad Grobami Wojennymi MSWojsk ${ }^{44}$. Mogło być ono jednak wydane jedy-

by ze Zjazdu Katedr Historycznoprawnych, Augustów 15-18 września 2002 roku, Białystok 2003, s. 669-670.

${ }^{40}$ M. Karczewska, M. Karczewski, Pro Patria. Miejsca pamięci I wojny światowej na przedpolu Twierdzy Osowiec, Białystok 2015, s. 23.

41 93. Zakres działania Biura Informac. Czerwonego Krzyża i stosunek tegoż do wojska, D.M.O.I. Nr 5166 Org. (Dz. Rozk. 1920, nr 5).

42 334. Zakres działania Biura Inf. Czerwonego Krzyża (B. I. C. K.) i jego stosunek do Wojska, O. I. Szt. 3596 Org. (Dz. Rozk. 1921, nr 17).

43 425. Nadsyłanie wykazów grobów wojskowych przez kapelanów do U. O. nad G. W. przy

D. O. G., B. P. I. 1058/20 (Dz. Rozk. 1920, nr 16).

44 887. Przewóz koleją zwłok żołnierzy polskich na rachunek M. S. Wojsk, S.W.N. 2582 Rel. (Dz. Rozk. 1920, nr 41). 
nie po okazaniu zaświadczenia, że zwłoki spoczywają poza obrębem zorganizowanego cmentarza (parafialnego, gminnego, garnizonowego lub wojennego). W grudniu 1920 r. zdecydowano, że państwo polskie będzie pokrywać koszty transportu zwłok żołnierzy francuskich poległych w Polsce, a także koszty pogrzebu żołnierzy francuskich, ale tylko tych wcielonych do armii polskiej i pochowanych w Polsce ${ }^{45}$.

Zakończenie działań wojennych umożliwiło uporządkowanie najświeższych mogił i cmentarzy. W początkach 1921 r. dowództwom okręgów generalnych w Warszawie, Lublinie i Lwowie polecono utworzenie grabarskich kolumn roboczych ${ }^{46}$. Każde z nich miało zorganizować po sześć kolumn roboczych po sto osób, które miały obchodzić poszczególne starostwa i porządkować znajdujące się na ich terenach groby. Do każdej kolumny miał być przydzielony dowódca w postaci oficera (podporucznika) lub urzędnika wojskowego, pomocnik dowódcy (sierżant lub podchorąży) oraz czterech podoficerów lub starszych szeregowych. Kolumny miały być wyposażone w odpowiednie narzędzia i składać się z jeńców wojennych, a w razie braku możliwości ich zorganizowania - z ludności cywilnej na zasadach kontraktowania. Należało wyszukiwać specjalistów lub ludzi uzdolnionych w tego typu pracach. Bezwzględnie zakazano tworzenia kolumn mieszanych, tj. składających z jeńców oraz ludności miejscowej. Wszelkie wydatki na ekshumacje, urządzanie grobów i utrzymanie kolumn miał pokrywać dział kontroli gospodarczej i intendentura danego okręgu generalnego. Urzędy opieki nad grobami wojennymi działające przy dowództwach okręgów generalnych miały w porozumieniu z poszczególnymi starostwami sporządzać dokładne ewidencje wszystkich mogił i cmentarzy wojennych, w szczególności tych, co do których planowano skomasowanie i ekshumację zwłok. Dowódcy kolumn roboczych i kierownicy techniczni mieli podlegać naczelnikom funkcjonujących na danym terenie urzędów opieki nad grobami wojennymi.

Podejmowano także próby innych form upamiętniania wojennych ofiar wojskowych. Dnia 26 stycznia 1921 r. MSWojsk pismem do MWRiOP wystąpiło z wnioskiem o porozumienie się $\mathrm{z}$ episkopatami w sprawie umieszczania $\mathrm{w}$ kościołach parafialnych imiennych tablic z nazwiskami poległych żołnierzy, parafian danej wspólnoty ${ }^{47} \mathrm{i}$ zaoferowało $\mathrm{w}$ tym celu przekazanie wszelkich potrzebnych danych. Dnia 29 kwietnia Departament Wyznań MWRiOP informował MSWojsk, że do pokrywania kosztów wykonania i montażu takich tablic żołnierzy powołano niedawno zawiązane Towarzystwo Żałobnego Krzyża ${ }^{48}$. Samą sprawę ich zamieszczania MWRiOP obiecało poprzeć przed właściwymi władzami duchownymi.

45 1040. Przewóz do Francji zwłok zmarłych żołnierzy francuskich, O. IV Szt. 8495 R. K. (Dz. Rozk. 1920, nr 50).

46 123. Utworzenie kolumn roboczych grabarskich, S. W. N. 2007. S. W. N. (Dz. Rozk. 1921, nr 7).

${ }^{47}$ AAN, MWRiOP, sygn. 659, k. 441.

${ }^{48}$ Ibidem, k. 439-440. 
Wkrótce po zakończeniu działań wojennych i uporządkowaniu najbardziej palących kwestii podległość urzędów opieki nad grobami wojennymi przesunięto spod dowództw okręgów generalnych na dowództwa okręgów korpusów ${ }^{49}$. Następnie z dniem 1 stycznia 1923 r. nastąpiła istotna zmiana w kwestii opieki nad grobami wojennymi, gdyż rozporządzeniem szefostwa Administracji Armii MSWojsk z dnia 20 listopada 1922 r. wszelkie agendy Głównego Urzędu Opieki nad Grobami Wojennymi przy MSWojsk wraz jego budżetem przeniesiono na Ministerstwo Robót Publicznych ${ }^{50}$. Urzędy opieki nad grobami wojennymi zostały przekształcone w referaty grobownictwa wojennego oraz włączone w struktury okręgowych dyrekcji robót publicznych przy urzędach wojewódzkich. W ten sposób przeszły pod administrację cywilną, a z racji tego, że zostały strukturalnie powiązane $\mathrm{z}$ administracją wojewódzką, na terenie każdego województwa grobownictwo wojenne było zarządzane odmiennie. $Z$ kolei zarząd nad istniejącymi cmentarzami garnizonowymi zlokalizowanymi w miejscowościach o większych skupieniach wojska z dniem 1 czerwca 1923 r. przekazano centralnemu organowi służby duszpasterskiej, tj. Kurii Biskupiej ${ }^{51}$.

\section{PRACE NAD USTAWĄ O GROBACH I CMENTARZACH WOJENNYCH}

Poprzez lokalne zarządzenia i okólniki odpowiednich urzędów próbowano załatwić najbardziej palące potrzeby i ustalić podstawowe zasady opieki nad grobami wojennymi na poszczególnych terenach. Nadal brakowało jednak aktu prawnego unifikującego przepisy $\mathrm{w}$ tej materii na terenie całego kraju, który wprowadziłby jednolite reguły oraz zastąpiłby przestarzałe i odmienne przepisy pozaborcze. Prace nad nim toczyły się w Ministerstwie Robót Publicznych, które 12 maja 1932 r. przesłało do konsultacji Ministerstwa Wyznań Religijnych i Oświecenia Publicznego projekt ustawy o grobach i cmentarzach wojennych ${ }^{52}$.

Zawierał trzynaście artykułów i kilka istotnych różnic w stosunku do przyjętej w roku następnym ustawy ${ }^{53}$. W art. 1 projektu za groby wojenne uznano ,groby żołnierzy, marynarzy oraz innych wojskowych, poległych w czasie i z powodu

${ }^{49}$ W. Dunin-Wąsowicz, Stużba duszpasterska (B. Niekatolicka) [w:] H. Mościcki, W. Dzwonkowski, T. Bałaban (red.), Dziesięciolecie odrodzenia Polskiej Siły Zbrojnej: 1918-1928, Warszawa 1928, s. 451; M. Karczewska, Sto lat będa trwać bez opieki niczyjej... Cmentarze wojenne z czasów I wojny światowej w Biatymstoku i powiecie białostockim, Białystok 2017, s. 77.

${ }_{50}$ 168. Ekshumacja i przewóz zwłok żołnierzy W. P. - unieważnienie rozkazu, W. W. N. 469. (Dz. Rozk. 1923, nr 13).

51 297. Ustanowienie cmentarzy garnizonowych, O. I. Szt, Gen. 6940. Org (Dz. Rozk. 1923, nr 22). Cmentarze garnizonowe zlokalizowane były w Warszawie (Powązki), Modlinie, Dęblinie, Lublinie, Kowlu, Wilnie, Grodnie, Łodzi, Krakowie, Lwowie, Poznaniu, Toruniu, Grudziądzu, Brześciu nad Bugiem i Przemyślu.

${ }^{52}$ AAN, MWRiOP, sygn. 659, k. 446.

${ }^{53}$ Ibidem, k. 447-454. 
działań wojennych" ${ }^{\text {4 }}$. Łatwo zauważyć, że projektodawca wzorował się tu na art. 225 traktatu wersalskiego. Cmentarzem wojennym określono grunt, na którym znajdowała się mogiła zbiorowa bądź pięć mogił pojedynczych.

Wedle postanowień projektu nie każdy grób wojenny miał podlegać bezwzględnej opiece. W art. 2 rozróżniono groby wojenne żołnierzy polskich, które bez względu na narodowość i wyznanie zmarłego miały być pamiątkami publicznymi oraz miały być szanowane i pielęgnowane, i groby wojenne, w których byli pochowani obywatele obcych państw ${ }^{55}$. Te miały być szanowane i utrzymywane tylko pod warunkiem wzajemności (obostrzenie to nie znalazło się w ostatecznym tekście ustawy).

W art. 3 projektu wymieniono także możliwości miejsca pochówku zwłok ekshumowanych z grobów wojennych (później w tej kwestii odsyłano do ustawy o chowaniu zmarłych i stwierdzaniu przyczyny zgonu z 1932 r.): mauzolea, krypty i ,inne podobne urządzenia" ${ }^{56}$. W art. 4 ujęto możliwości wywłaszczania gruntów potrzebnych na groby i cmentarze wojenne, ustalając je ściśle dla cmentarzy tradycyjnych (po $4 \mathrm{~m}^{2}$ dla każdego pojedynczego grobu oraz dodatkowa powierzchnia na aleje, dojście do drogi publicznej i cele ornamentacyjne) i uznaniowo dla mauzoleów i krypt (,stosownie do potrzeb oraz wymagań technicznych i estetycznych") ${ }^{57}$. Nie wspomniano jednak o możliwości nabycia gruntu przez Skarb Państwa w drodze umowy.

Wraz z art. 5 planowano unormowanie odszkodowań za grunty już zajęte przez groby i cmentarze wojenne ${ }^{58}$. Mogłyby być one przyznawane ich właścicielom, jednak tylko wtedy, gdyby byli w nich pochowani uczestnicy enumeratywnie wymienionych konfliktów zbrojnych (wojna światowa, wojna polsko-bolszewicka, walki o oswobodzenie i zjednoczenie ziem polskich). W przypadku braku ugody wysokość odszkodowania miałaby ustalać powiatowa władza administracji ogólnej na podstawie oszacowania dokonanego przez naczelnika gminy lub sołtysa, z przybraniem biegłego przy kwotach powyżej $1000 \mathrm{zt}^{59}$. Grunt przechodziłby wtedy na własność Skarbu Państwa, a niezadowolony właściciel miałby w ciągu 30 dni prawo do wystąpienia do sądu w tej sprawie. Dwuletni termin na zwrócenie się o odszkodowanie miałby ustalić minister robót publicznych. Ogólny zwierzchni nadzór nad grobownictwem wojennym także powierzono MRP ${ }^{60}$. Nie licząc odmiennej redakcji niektórych przepisów i kwestii drobniejszej wagi, pozostałe regulacje zawarte $\mathrm{w}$ projekcie były zbieżne z przyjętą $\mathrm{w}$ roku następnym ustawą.

\footnotetext{
54 Ibidem, k. 447.

55 Ibidem, k. 448.

56 Ibidem.

57 Ibidem, k. 448-449.

58 Ibidem, k. 450.

59 Ibidem, k. 451.

60 Ibidem, k. 452.
} 
W uzasadnieniu projektu podkreślono, że ratyfikowane przez Polskę traktaty pokojowe (traktat wersalski, traktat w Saint-Germain-en-Laye, traktat ryski) nałożyły na państwo obowiązek utrzymywania grobów i cmentarzy wojennych niezależnie od narodowości i przynależności państwowej poległych ${ }^{61}$. Projektowana ustawa miała na celu stworzenie norm prawnych w celu uregulowania kwestii opieki nad takimi obiektami, przede wszystkim w stosunku do poległych w czasie wojny światowej, wojny polsko-bolszewickiej oraz walk o oswobodzenie i zjednoczenie ziem polskich. Normowała też tego typu sprawy na przyszłość.

Dotychczas wykonane prace z zakresu grobownictwa wojennego miały polegać na opracowaniu ewidencji poległych, mogił i cmentarzy wojennych; opracowaniu planu cmentarzy; przeprowadzaniu ekshumacji zwłok z mogił rozrzuconych po polach, lasach, ogrodach i innych losowych miejscach; przeniesieniu tych zwłok na cmentarze; remoncie cmentarzy; stawianiu pomników i renowacji starych monumentów, a także innych pracach porządkowych, takich jak ogradzanie cmentarzy $\mathrm{i}$ ich oznaczanie na tablicach informacyjnych ${ }^{62}$. Koszty wykonanych prac wyceniono na 4 miliony złotych. Znaczna część cmentarzy miała być już uporządkowana, remontu miało jednak wymagać jeszcze ok. 3,6 tysiąca $\mathrm{z}$ nich. W celu ograniczenia wydatków na utrzymanie nekropolii planowano komasację niektórych cmentarzy poprzez przeniesienie części szczątków z mniejszych obiektów. Pozostałe do wykonania prace wyceniono na kolejne kilka milionów złotych ${ }^{63}$.

Według projektodawcy obowiązek bieżącej konserwacji już odnowionych i uporządkowanych cmentarzy można było przenieść na gminy jako na instytucje prawa publicznego, co miałoby się odbyć bez specjalnych ciężarów dla gmin ${ }^{64}$. Palącą potrzebą miało być uregulowanie stanu prawnego gruntów prywatnych zajętych na cmentarze wojenne w czasie Wielkiej Wojny, które projektodawca oszacował na ok. 300 hektarów ${ }^{65}$. Za istotną uznano także propozycję wywłaszczenia gruntów potrzebnych na urządzenie cmentarza wojennego, co umożliwiłoby planowanie ekshumacji i ponownych pochówków na przyszłośćc6. Do uzasadnienia dołączono także tabelę $\mathrm{z}$ danymi dotyczącymi grobownictwa wojennego $w$ innych państwach europejskich ${ }^{67}$. Liczba mogił, kwoty wydawane na ich utrzymanie i określenie podmiotów za nie odpowiedzialnych ukazują skalę problemu grobownictwa w całej Europie, a także możliwości i podejście poszczególnych państw do tego trudnego tematu.

\footnotetext{
61 Ibidem, k. 455.

62 Ibidem, k. 456.

63 Ibidem.

64 Ibidem, k. 457.

65 Ibidem, k. 458.

66 Ibidem, k. 459.

67 Ibidem, k. 460-461.
} 


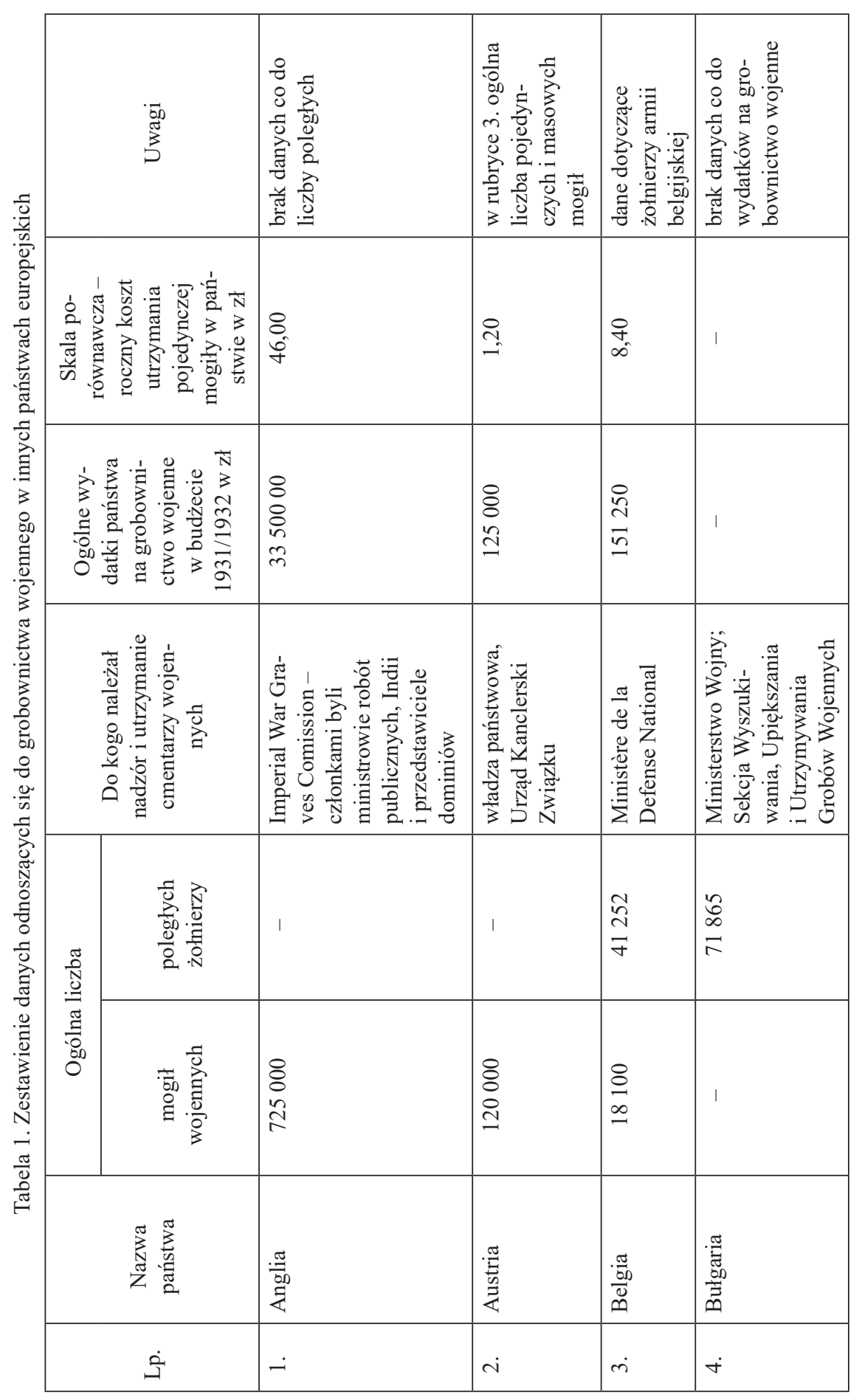




\begin{tabular}{|c|c|c|c|c|c|}
\hline 1 & 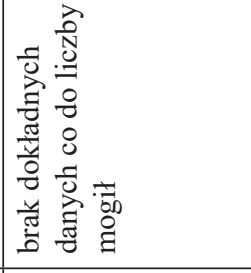 & 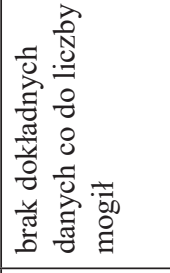 & 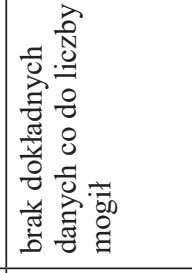 & 1 & 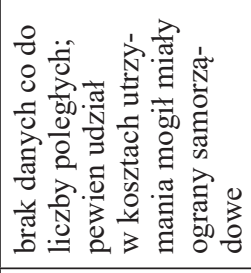 \\
\hline$\stackrel{\circ}{=}$ & $\stackrel{n}{\approx}$ & $\begin{array}{l}\dot{m} \\
\text { In } \\
\dot{ \pm}\end{array}$ & $\begin{array}{l}\text { त् } \\
\text { in }\end{array}$ & $\stackrel{8}{-}$ & $\begin{array}{l}\infty \\
\infty \\
0\end{array}$ \\
\hline $\begin{array}{l}8 \\
\delta \\
a\end{array}$ & $\begin{array}{l}q \\
d \\
m \\
=\end{array}$ & \begin{tabular}{l}
8 \\
0 \\
0 \\
8 \\
\hdashline
\end{tabular} & 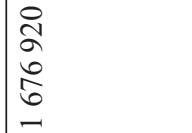 & $\begin{array}{l}8 \\
0 \\
0 \\
0 \\
i \\
i n\end{array}$ & $\begin{array}{l}8 \\
8 \\
0 \\
i n\end{array}$ \\
\hline 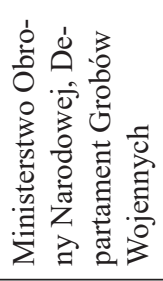 & 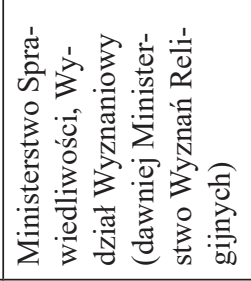 & 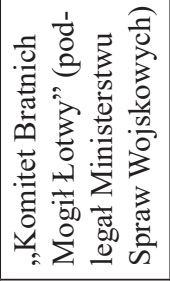 & 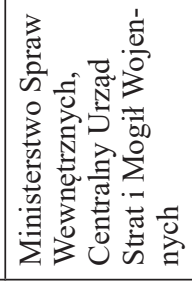 & 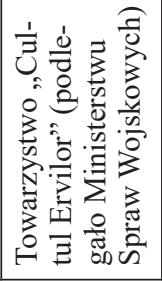 & 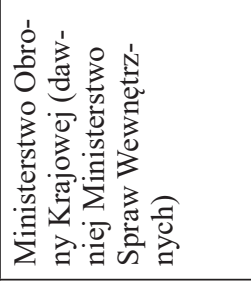 \\
\hline 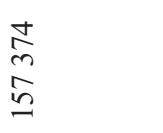 & 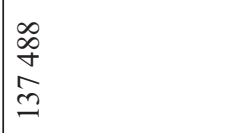 & $\begin{array}{l}8 \\
0 \\
0 \\
0\end{array}$ & $\frac{8}{8}$ & $\begin{array}{l}8 \\
8 \\
8 \\
\infty \\
\infty\end{array}$ & 1 \\
\hline $\begin{array}{l}8 \\
\delta \\
\text { }\end{array}$ & 1 & 1 & 1 & $\begin{array}{l}8 \\
8 \\
8 \\
o \\
+\end{array}$ & $\begin{array}{l}8 \\
8 \\
\infty\end{array}$ \\
\hline 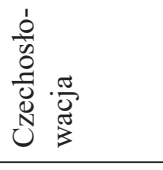 & 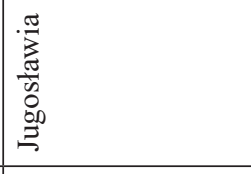 & 䍃 & 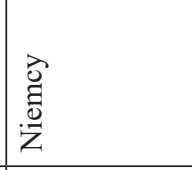 & $\begin{array}{l}\text { 㸓 } \\
\text { 竞 }\end{array}$ & $\frac{3}{50}$ \\
\hline in & $0^{\circ}$ & $\therefore$ & $\infty^{\circ}$ & $a^{\circ}$ & $\stackrel{\circ}{0}$ \\
\hline
\end{tabular}




\begin{tabular}{|c|c|c|}
\hline 1 & 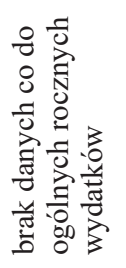 & 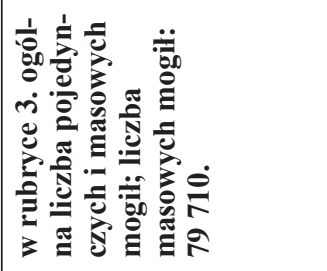 \\
\hline $\begin{array}{l}\stackrel{o}{q} \\
\stackrel{2}{2}\end{array}$ & 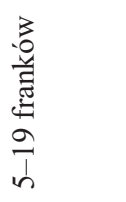 & 足 \\
\hline $\begin{array}{l}8 \\
8 \\
0 \\
i n \\
m\end{array}$ & 1 & $\begin{array}{l}8 \\
8 \\
0 \\
\text { ñ }\end{array}$ \\
\hline 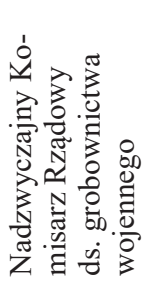 & 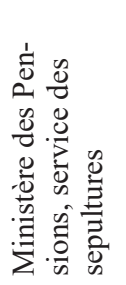 & 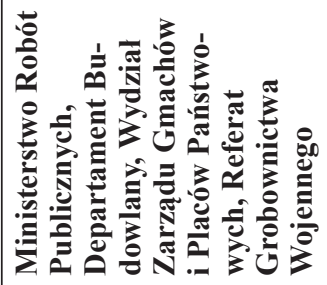 \\
\hline $\begin{array}{l}8 \\
\vdots \\
n \\
\end{array}$ & $\begin{array}{l}8 \\
8 \\
0 \\
0 \\
m \\
-\end{array}$ & 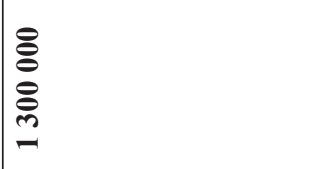 \\
\hline 1 & 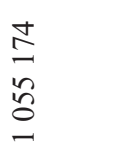 & $\begin{array}{l}\frac{0}{6} \\
\frac{1}{6} \\
\text { in }\end{array}$ \\
\hline $\begin{array}{l}\frac{3}{0} \\
\frac{0}{3} \\
\frac{3}{3}\end{array}$ & 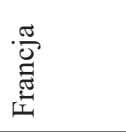 & $\begin{array}{l}\frac{\pi}{\pi} \\
\frac{\pi}{0} \\
\stackrel{0}{0}\end{array}$ \\
\hline$\doteq$ & $\stackrel{\sim}{\sim}$ & $\dot{2}$ \\
\hline
\end{tabular}


Niecały miesiąc później, 6 czerwca 1932 r., minister wyznań religijnych i oświecenia publicznego Janusz Jędrzejewicz informował o braku zastrzeżeń do przedłożonego projektu ${ }^{68}$. 1 lipca tego samego roku zlikwidowano Ministerstwo Robót Publicznych, zaś jego kompetencje w zakresie grobownictwa wojennego przekazano Ministerstwu Spraw Wewnętrznych ${ }^{69} .27$ października MSW przesłało projekt do Prezydium Rady Ministrów, a 14 listopada w Biurze Prawnym Prezesa Rady Ministrów odbyła się poświęcona mu konferencja międzyministerial$\mathrm{na}^{70}$. Jej efektem były ostatnie poważniejsze zmiany i ustalenie niemal finalnego kształtu projektu.

Projekt zawierał dwanaście artykułów i był już niemal taki, jak przedstawiony wkrótce Sejmowi. Jedyne różnice dotyczyły art. 10 odsyłającego do kilku konkretnych przepisów niedawno przyjętej ustawy o chowaniu zmarłych i stwierdzaniu przyczyny zgonu zamiast późniejszego odwołania się w całości do przepisów tej ustawy ${ }^{71}$. W art. 11 brakowało także wymienionego w późniejszej wersji ministra opieki społecznej jako jednego z powołanych do wykonania ustawy szefów resortów. 12 grudnia 1932 r. Prezydium Rady Ministrów rozesłało tak przygotowany tekst do akceptacji zainteresowanym ministerstwom, MWRiOP żadnych uwag nie zgłosiło ${ }^{72}$.

\section{SEJM I SENAT WOBEC PROJEKTU USTAWY O GROBACH I CMENTARZACH WOJENNYCH}

W końcu projekt opuścił gmachy ministerialne i trafił na ścieżkę legislacyjną. Pierwsze czytanie projektu ustawy o grobach i cmentarzach wojennych odbyło się na 77. posiedzeniu Sejmu III kadencji w dniu 27 stycznia 1933 r. ${ }^{73}$ Treść projektu była tożsama $\mathrm{z}$ jego ostatnią wersją przesyłaną do uzgodnienia między ministerstwami $^{74}$. Jedynymi zmianami były drobne, wspomniane już korekty w art. 10 i 11, które świadczą o tym, że dyskusje i prace nad nim toczyły się niemal do ostatniej chwili przed przekazaniem go na drogę parlamentarną.

${ }^{68}$ Ibidem, k. 462.

${ }^{69}$ Rozporządzenie Prezydenta Rzeczypospolitej z dnia 21 maja 1932 r. w sprawie zniesienia urzędu Ministra Robót Publicznych (Dz. U. nr 51, poz. 479).

${ }^{70}$ AAN, MWRiOP, sygn. 659, k. 476.

${ }^{71}$ Ibidem, k. 478-483.

72 Ibidem, k. 476-477.

${ }^{73}$ Biblioteka Sejmowa, Parlamentaria polskie 1919-1997 [dalej: BS, PP], Sejm 1919-1939, 3 kadencja 1930-1935 [dalej: Sm3k], Stenogramy [dalej: St], Sprawozdanie Stenograficzne z 77 posiedzenia w dniu 27 lutego 1933 r. [dalej: SS77], s. 12.

${ }^{74}$ BS, PP, Sm3k, Druki sejmowe [dalej: DS.], Rządowy projekt ustawy o grobach i cmentarzach wojennych [dalej: Druk nr 667], s. 1. 
Treść uzasadnienia była analogiczna do uzasadnienia załączonego w wersji projektu przesłanego 12 maja 1932 r., lecz nieco krótsza i zwięźlej zredagowana. Według danych posiadanych przez MSW na terenie Rzeczypospolitej znajdowało się 10255 cmentarzy wojennych (w poprzedniej wersji 10 755) mieszczących 427899 mogił pojedynczych (wcześniej 487 899) i 79712 mogił zbiorowych ${ }^{75}$. Łącznie miało w nich spoczywać ok. 1,3 miliona poległych. Różnice w podanych liczbach były na tyle niewielkie, a przy tym charakterystyczne (w obu przypadkach różnica jednej cyfry), że nie była to prawdopodobnie wina zmian w zgromadzonych danych, a zwykłej omyłki pisarskiej w którejś wersji (zapewne w tej starszej, roboczej).

Załączono również zestawienie dotyczące grobownictwa wojennego $\mathrm{w}$ innych państwach europejskich, w którym zawarte dane były tożsame z tymi przedstawionymi w tabeli przesyłanej wraz z projektem w maju 1932 r. Uzupełniono jednak dane na temat Francji, a także zaktualizowano, że w Polsce podmiotem odpowiedzialnym w tej kwestii stało się Ministerstwo Spraw Wewnętrznych ${ }^{76}$.

Pod koniec uzasadnienia pokrótce przedstawiono treść poszczególnych artykułów projektu, skupiając się jedynie na art. 3 dotyczącym odszkodowań ${ }^{77}$. Uznano, że skoro sytuacja Skarbu Państwa nie pozwalała na natychmiastowe wypłacenie ich właścicielom zajętych na cmentarze wojenne gruntów, to termin wypłaty takich odszkodowań miałby ustalić minister spraw wewnętrznych w porozumieniu z ministrem skarbu.

Marszałek Kazimierz Świtalski odesłał projekt do dalszych prac w Komisji Administracyjnej ${ }^{78}$. Na posiedzenie plenarne powrócił on na 93. posiedzeniu Sejmu III kadencji w dniu 8 marca 1932 r. Obrady prowadził wicemarszałek Wacław Makowski, który oddał głos sprawozdawczyni Komisji Administracyjnej Ludwice Wolskiej ${ }^{79}$, posłance klubu Bezpartyjnego Bloku Współpracy z Rządem ${ }^{80}$.

Sprawozdawczyni przypominała, że polska ziemia była sceną krwawych walk, na której życie straciło 1,3 miliona osób ${ }^{81}$. Po ofiarach w polskich granicach miało pozostawać ok. 80 tysięcy mogił zbiorowych i ponad pół miliona mogił pojedynczych. Rozpatrywana ustawa miała się zająć kwestią cmentarzy i grobów

${ }^{75}$ BS, PP, Sm3k, DS, Druk nr 667, s. 2.

76 Ibidem, s. 3.

77 Ibidem, s. 4.

${ }_{78}$ BS, PP, Sm3k, St, SS77, s. 12.

${ }^{79}$ Ludwika Wolska (1895-bd) - posłanka na Sejm RP III kadencji (1930-1935) z ramienia Bezpartyjnego Bloku Współpracy z Rządem, jedna z najaktywniejszych posłanek na mównicy sejmowej. Zob. P. Fiktus, Poselska aktywność kobiet na mównicy sejmowej w dobie II RP [w:] M. Sadowski (red.), Wrocławskie Studia Erazmiańskie, Wrocław 2015, s. 557-558.

${ }^{80}$ BS, PP, Sm3k, St, Sprawozdanie Stenograficzne z 93 posiedzenia w dniu 8 marca 1933 r. [dalej: SS93], s. 17-18.

${ }^{81}$ BS, PP, Sm3k, St, SS93, s. 18. 
wojennych, nad którymi powinność opieki miała wynikać nie tylko z należnego im pietyzmu, ale także z powodów natury prawnej. W tym kontekście wspomniała o art. 225 i 226 traktatu wersalskiego oraz art. IX traktatu ryskiego, w których sygnatariusze zobowiązują się do opieki nad mogiłami uczestników wojny bez względu na narodowość czy wyznanie. Istotne miało być również uregulowanie sprawy gruntów prywatnych zajętych przez groby wojenne, które oszacowano na ok. 300 hektarów. Rządy państw uczestniczących w wojnie światowej wydawały ogromne sumy na utrzymanie mogił wojennych, np. Anglia w roku budżetowym 1931/1932 przeznaczyła na ten cel równowartość 33,5 miliona zł, a Włochy 3 miliony $z^{82}$. Z kolei Polska w budżecie na rok 1933/1934 przewidziała na te potrzeby „sto dwadzieścia kilka tysięcy złotych” i do całkowitego uporządkowania tej kwestii wciąż potrzebne było parę milionów złotych.

Posłanka Wolska zgodnie z wnioskiem Komisji Administracyjnej prosiła Wysoką Izbę o przyjęcie projektu bez zmian, co spotkało się z brawami posłów BBWR $^{83}$. Nikt nie zgłosił się do dyskusji, toteż wicemarszałek Makowski zarządził głosowanie. Za przyjęciem głosowała większość zarówno w drugim, jak i trzecim czytaniu, więc ustawa o grobach i cmentarzach wojennych została przyjęta przez Sejm.

Przez Izbę Wyższą parlamentu została ona rozpatrzona na 51. posiedzeniu Senatu III kadencji w dniu 14 marca $1933 r{ }^{84}$ Krótkie podsumowanie posiedzenia Komisji z 10 marca sprowadzało się do wniosku o uchwalenie ustawy w brzmieniu przyjętym przez Sejm z tą zmianą, że w art. 1 rozszerzono katalog mogił uznanych za groby wojenne o jeszcze jedną pozycję: groby uchodźców z 1915 r. ${ }^{85}$

Sprawozdawcą Komisji okazał się senator Olgierd Jeleński z BBWR ${ }^{86}$, który podkreślił, że w pierwszej kolejności za groby wojenne uznano mogiły poległych

${ }^{82}$ Ibidem, s. 19.

83 Ibidem.

${ }^{84}$ BS, PP, Senat 1922-1939, 3 kadencja 1930-1935 [dalej: St3k], Stenogramy [dalej: St], Sprawozdanie Stenograficzne z 51 posiedzenia Senatu Rzeczypospolitej dnia 14 marca 1933 roku [dalej: SS51], s. 70.

${ }^{85}$ BS, PP, St3k, Odbitki, Odbitka nr 243.

${ }^{86}$ Olgierd Jeleński (1881-po 1941) - ziemianin, przedsiębiorca, działacz społeczny, samorządowiec, polityk. Ukończył gimnazjum w Mińsku, studiował na Politechnice Warszawskiej i Uniwersytecie w Dorpacie (zdobył tytuł inżyniera). Od 1917 r. członek Polskiej Organizacji Wojskowej, w latach 1922-1932 członek Wydziału Powiatowego w Nieświeżu. Założyciel m.in. fabryki korków, krochmalni, sadu jabłkowego, ochotniczej straży pożarnej, organizator szkoły powszechnej. Senator III kadencji (1930-1935) wybrany z województwa nowogródzkiego, członek klubu BBWR. We wrześniu 1939 r. aresztowany przez NKWD, latem 1941 r. wywieziony w kierunku Archangielska. Zob. Jeleński Olgierd Augustyn 1881-po 1941, biogram w bazie Sejmu RP, https:// bs.sejm.gov.pl/F? func $=$ find-b\&request $=000002123 \&$ find_code=SYS\&local_base $=$ ARS10 [dostęp: 14.01.2019]. 
w walkach o niepodległość ojczyzny ${ }^{87}$. Następne wymienione mogiły miały podlegać tej klasyfikacji ze względu na zobowiązania wynikające z traktatów pokojowych, które nakładały na państwo polskie obowiązek traktowania grobów obcych na równi z polskimi. Środki przewidziane na grobownictwo wojenne w budżecie na rok 1933/1934 miały wynosić 233943 zł, co stanowiło prawie dwukrotność sumy podawanej zaledwie kilka dni wcześniej przez posłankę Wolską i było błędem Jeleńskiego, gdyż odnosił się on do kwoty zapisanej w budżecie na rok 1932/193388.

Komisja po analizie wszystkich postanowień ustawy doszła do wniosku, że pominięto w niej istotną grupę grobów, czyli groby uchodźców z $1915 \mathrm{r}^{89}$ Traktat ryski $\mathrm{w}$ art. IX nakładał na obie strony obowiązek opieki na grobami zakładników, jeńców cywilnych, osób internowanych, wygnańców, uchodźców i emigrantów. Członkowie Komisji zwrócili uwagę, że zdecydowana większość mogił uchodźców znajduje się po sowieckiej stronie ówczesnej granicy, gdyż wojenne koleje losu zmusiły wielu Polaków do niechcianych, męczących i nierzadko śmiertelnych podróży. Mimo niewielkiej liczby analogicznych grobów rosyjskich uchodźców na polskich ziemiach takie określenie w ustawie miało w przyszłości pomóc upomnieć się o należytą opiekę nad uchodźczymi grobami ze strony wschodniego sąsiada.

Nikt nie zgłosił się do dyskusji, więc marszałek Władysław Raczkiewicz przeszedł najpierw do głosowania nad wprowadzeniem komisyjnej poprawki, a potem nad całością ustawy. W obu przypadkach większość zgromadzonych senatorów zagłosowała ,za”, tym samym ustawa o grobach i cmentarzach wojennych została przyjęta.

\section{USTAWA Z 1933 ROKU \\ I JEJ ROZPORZĄDZENIE WYKONAWCZE Z 1936 ROKU}

Ustawa o grobach i cmentarzach wojennych weszła w życie 30 maja 1933 r.90 23 października 1936 r. jej przepisy wsparło rozporządzenie wykonawcze, które

${ }^{87}$ BS, PP, St3k, St, SS51, s. 70.

${ }^{88}$ Ibidem, s. 71. Łączna kwota zapisana w ustawie skarbowej na okres od 1 kwietnia 1933 r. do 31 marca 1934 r. w części 7. (Ministerstwo Spraw Wewnętrznych), punkcie I (Wydatki zwyczajne), dziale 3. (Służba techniczna) w paragrafach 17. (Grobownictwo wojenne), 18. (Grobownictwo wojenne z czasów wojny światowej) i 19. (Grobownictwo wojenne z czasów wojny Polski z Z.S.S.R. i powstań narodowych) wynosiła 124390 zł (Dz. U. 1933, nr 23, poz. 186). Podawana przez Jeleńskiego kwota była niemal tożsama ze środkami zapisanymi w poprzedniej ustawie skarbowej (na okres od 1 kwietnia 1932 r. do 31 marca 1933 r.), gdyż w części 14. (Ministerstwo Robót Publicznych), punkcie I (Wydatki zwyczajne), dziale 2. (Roboty publiczne), rozdziale 7. (Grobownictwo wojenne) zapisano kwotę 233940 zł (Dz. U. 1932, nr 23, poz. 175).

${ }^{89}$ Ibidem.

${ }^{90}$ Ustawa z dnia 28 marca 1933 r. o grobach i cmentarzach wojennych (Dz. U. nr 39, poz. 311). 
weszło w życie 7 listopada 1936 r. ${ }^{91}$ (uchylone dopiero w 2016 r. ${ }^{92}$ ). Za groby wojenne uznano groby poległych w walkach o niepodległość i zjednoczenie państwa polskiego, osób wojskowych poległych lub zmarłych w czasie działań wojennych (bez względu na narodowość), osób zmarłych przy wykonywaniu zleconych im czynności przy formacji wojskowej, jeńców wojennych, osób internowanych i uchodźców z 1915 r. (art. 1 ustawy). Jeśli tego typu osoby zostały pochowane w grobach rodzinnych, takie mogiły nie zyskiwały statusu grobów wojennych. Co do zasady groby wojenne miały być grupowane na specjalnie im przeznaczonych cmentarzach wojennych. Wszystkie miały być pielęgnowane i otaczane należnym szacunkiem, niezależnie od narodowości i wyznania osób w nich pochowanych (art. 2).

Grunty zajęte przez groby i cmentarze wojenne, a także te przeznaczone na ich organizację, Skarb Państwa nabywał w drodze umowy (art. 3). W razie jej niezawarcia mógł je nabyć w wyniku wywłaszczenia na potrzeby urządzeń użyteczności publicznej. W drodze rozporządzenia z 6 grudnia 1934 r. ustalono termin, od którego powyższe postanowienie miało być stosowane do gruntów zajętych w dniu wejścia ustawy w życie, określono go na 1 kwietnia 1940 r. ${ }^{93}$ Prawo zarządzenia ekshumacji i przeniesienia do innego grobu przysługiwało władzy, z umotywowaną prośbą w tej sprawie mogła zwrócić się też rodzina lub otoczenie zmarłej osoby celem przeniesienia zwłok na inny cmentarz w kraju lub za granicą bądź sprowadzenia ich do kraju (art. 4). W przypadku ekshumacji i przeniesienia na inny cmentarz w kraju, kompetencje w tym zakresie miał wojewoda ( $\$ 2$ rozporządzenia). Z kolei sprawy sprowadzenia zwłok z zagranicy oraz wywiezienia do innego kraju należały do zakresu działania ministra spraw wewnętrznych, dotyczyło to również zatwierdzania planów cmentarzy wojennych (§ 1). Musiał jednak w tych kwestiach działać w porozumieniu z ministrem spraw wojskowych. O planowanej z urzędu ekshumacji władza miała zawiadomić rodzinę zmarłego oraz wezwać do oświadczenia, czy rodzina nie zamierza zabrać zwłok z cmentarza lub grobu wojennego w celu pochowania ich w grobie rodzinnym (§ 3).

Wszelkie ingerencje w integralność cmentarza i grobów wojennych, takie jak roboty ziemne, wznoszenie pomników czy innych urządzeń, wymagały zezwolenia wojewody (art. $5 \S 2$ ). Wymagano go również przy ich fotografowa-

${ }^{91}$ Rozporządzenie Ministra Spraw Wewnętrznych z dnia 23 października 1936 r. wydane w porozumieniu z Ministrami Spraw Wojskowych i Opieki Społecznej w sprawie wykonania ustawy z dnia 28 marca 1933 r. o grobach i cmentarzach wojennych (Dz. U. nr 85, poz. 595).

92 Ustawa z dnia 29 kwietnia 2016 r. o zmianie ustawy o Instytucie Pamięci Narodowej-Komisji Ścigania Zbrodni przeciwko Narodowi Polskiemu oraz niektórych innych ustaw (Dz. U. poz. 749).

${ }_{93}$ Rozporządzenie Ministra Spraw Wewnętrznych z dnia 6 grudnia 1934 r. wydane w porozumieniu z Ministrem Skarbu w sprawie ustalenia terminu nabywania przez Skarb Państwa gruntów zajętych przez groby i cmentarze wojenne (Dz. U. nr 110, poz. 979). 
niu i kopiowaniu planów sytuacyjnych. W przypadku samowolnego przekroczenia zakresu pozwolenia, samowolnej ekshumacji bądź samowolnych zmian w strukturze grobów lub cmentarzy wojennych, a także w przypadku zachowań nielicujących z powagą miejsca, jeśli czyn nie stanowił przestępstwa, sprawca podlegał karze administracyjnej w postaci aresztu do 6 tygodni lub grzywny do $750 \mathrm{zł}$ (art. 9).

Opiekę nad grobami i cmentarzami wojennymi miało sprawować państwo, nadzór w tej kwestii miał zaś sprawować minister spraw wewnętrznych, przy zachowaniu uprawnień wyznaniowych osób prawnych, zarządów gmin i instytucji wojskowych (art. 6). Koszt ich utrzymania pokrywał Skarb Państwa, a wojewódzka władza administracji ogólnej mogła przekazać fundusze na ten cel gminie, o ile gmina nie podjęła się tego bezpłatnie. Zarząd właściwej gminy miał bezpośrednio czuwać nad stanem grobów i cmentarzy wojennych, a w razie uszkodzeń zobowiązany był powiadomić wojewodę (§ 4). Minister mógł także powierzyć obowiązek utrzymywania grobów i cmentarzy wojennych instytucjom społecznym i ich zrzeszeniom za ich zgodą, a nadzór nad tymi czynnościami sprawował wtedy wojewoda (§ 6). Jeżeli tego nie uczyniono, to bezpośredni dozór nad nimi sprawowały gminy (art. 7). Jeśli przekazano gminie, wraz funduszami na ten cel, obowiązek ich utrzymywania bądź gmina sama podjęła się tego bezpłatnie, to do jej obowiązków należała także konserwacja i remont tych obiektów (§ 5). Czynności te, niezależnie od podmiotu wykonującego, miały być przeprowadzane w porozumieniu z właściwymi władzami wojskowymi (§ 7).

W innych kwestiach groby i cmentarze wojenne miały podlegać ustawie o chowaniu zmarłych i stwierdzaniu przyczyny zgonu z 1932 r., o ile jej zapisy nie były sprzeczne z przepisami ustawy niniejszej (art. 10). Wykonanie jej powierzono ministrowi spraw wewnętrznych w porozumieniu $\mathrm{z}$ innymi ministrami w działach przez nich nadzorowanych (art. 11), a obowiązywać miała na terenie całego kraju (z wyjątkiem województwa śląskiego w kwestii odesłań do ustawy z 1932 r., która nie obowiązywała na jego obszarze). Dekretem prezydenckim z 19 listopada 1938 r. rozciągnięto jej moc obowiązującą na zajęte ziemie Zaolzia ${ }^{94}$.

Poszczególne kwestie z zakresu grobownictwa organizowano i precyzowano również za pomocą ministerialnych okólników. Jeszcze w trakcie procedowania nad projektem ustawy w marcu 1933 r. MSW skierowało do wojewodów okólnik, w którym proszono o wydanie zarządzeń mających zdyscyplinować personel grobownictwa wojennego w zakresie należytego i dokładnego wypełniania

${ }^{94}$ Dekret Prezydenta Rzeczypospolitej z dnia 19 listopada 1938 r. o rozciągnięciu mocy obowiązującej niektórych aktów ustawodawczych na odzyskane ziemie Śląska Cieszyńskiego (Dz. U. nr 90, poz. 612). 
obowiązków przy ekshumacjach ${ }^{95}$. Do MSW miały bowiem docierać niepokojące zgłoszenia o pozostawionych na miejscach ekshumacji niepogrzebanych kościach żołnierzy i resztkach umundurowania wojskowego. Wszystkie wydobyte szczątki i przedmioty miały być ponownie pochowane w nowo wyznaczonych mogiłach. Przedmioty wartościowe po ich zdezynfekowaniu miały być raz w roku przesyłane do MSW. Roboty ekshumacyjne miały być prowadzone pod ścisłym nadzorem urzędu wojewódzkiego i zakończone protokołem podpisanym przez przedstawiciela tego urzędu, przedstawiciela policji państwowej, wójta lub sołtysa oraz lekarza powiatowego (jeśli był obecny podczas ekshumacji). W maju 1934 r. zaktualizowano wzory formularzy takich protokołów ${ }^{96}$. Miały być one w miarę możliwości sporządzane zbiorczo, tj. przy przenoszeniu więcej niż jednej mogiły z danego miejsca miał być spisywany jeden protokół, a nie oddzielne dla każdej mogiły jak do tej pory. W marcu 1939 r. dopracowano system inspekcji ze strony działu techniczno-budowlanego $\mathrm{MSW}^{97}$. Do inspekcji obiektów grobownictwa wojennego właściwi byli urzędnicy techniczni referatów budowlanych starostw powiatowych, a kontrola miała obejmować prowadzenie ewidencji, przeprowadzane ekshumacje, utrzymanie grobów, komasację grobów, remonty grobów i cmentarzy, urządzanie cmentarzy wojennych oraz budowę pomników wojennych.

\section{PODSUMOWANIE}

Odrodzone państwo polskie musiało borykać się z wieloma problemami niemal w każdej dziedzinie, na którą mogło oddziaływać prawo i administracja, co sprawiało, że kwestia grobownictwa wojennego miała niską pozycję na liście spraw do systemowego uporządkowania. $Z$ toczonych dyskusji przebijała bowiem retoryka pierwszorzędności powinności państwowych wobec organizacji życia powojennego i polepszenia statusu obywateli, tak więc polegli musieli ustąpić pierwszeństwa ocalałym i poczekać na poprawę sytuacji budżetowej oraz usprawnienie administracji. Trudno nie zgodzić się z takim określeniem wagi ówczesnych obowiązków, jednak wobec prawie pół miliona mogił rozsianych w różnych miejscach całego kraju równie trudno było uznać grobownictwo wojenne

${ }_{95}$ 50. Okólnik Nr 20 z dnia 7 marca 1933 r. (BZ. 3 9/1/2) w sprawie starannego wykonywania czynności przy ekshumacji zwłok żołnierzy, poległych w wojnie europejskiej i w wojnie Polski z Z. S. R. R. (Dz. Urz. MSW nr 4).

96 137. Okólnik Nr 71 z dnia 24 maja 1934 r. o sporządzaniu protokółów ekshumacyjnych przy komasacji cmentarzy wojennych, BZ 42-og-2 (Dz. Urz. MSW nr 14).

97 42. Okólnik Nr 12 z dnia 20 marca 1939 r. w sprawie ogólnych zasad inspekcji wojewódzkich w dziale służby technicznej Min. Spraw Wewnętrznych, Nr BB 1-48-39 (Dz. Urz. MSW nr 7). 
za problem błahy. Stanowiły o tym względy kulturowe, czyli cywilizacyjny obowiązek uporządkowania i stałej pielęgnacji miejsc pochówku, względy prawne związane ze stosunkami międzynarodowymi, czyli powinność opieki nad mogiłami wojennymi wynikająca z podpisanych przez Polskę traktatów, oraz względy gospodarcze, czyli zajęcie przez groby i cmentarze wielu gruntów prywatnych, co uniemożliwiało ich użytkowanie.

Wydaje się, że wagę problemu dostrzeżono dość szybko, gdyż dyskusje nad jego systemowym rozwiązaniem na poziomie ministerialnym rozpoczęto już w 1919 r. Jednak początkowe spychanie odpowiedzialności z jednego resortu na drugi świadczy o braku jasnej koncepcji działań i niedostatecznej ocenie ogromu potrzeb w tej kwestii. Poszczególni zainteresowani chcieli jak najszybciej oddelegować sprawy grobownictwa wojennego do Ministerstwa Robót Publicznych, na które najłatwiej było je zrzucić. Szczególnie dziwić może początkowa niechęć do zajęcia się nimi Ministerstwa Spraw Wojskowych oraz Konsystorza Polowego bądź Kościoła w ogóle. Wydawałoby się, że to właśnie tym podmiotom powinno zależeć nie tylko na systemowym uporządkowaniu grobownictwa, ale także na aktywnym uczestnictwie w procesie jego kształtowania, ze względów informacyjnych, technicznych i moralnych oraz duchowych i społeczno-religijnych. MSWojsk szybko zmieniło jednak retorykę i właśnie ono odpowiadało za funkcjonujące w latach 1919-1923 urzędy opieki nad grobami wojennymi.

Ich późniejsza likwidacja i powrót do koncepcji przeniesienia kompetencji w sprawie grobownictwa wojennego na MRP, a w zasadzie na jego oddziały terenowe działające przy urzędach wojewódzkich, świadczy przede wszystkim o próbach dokonania oszczędności $\mathrm{w}$ tej dziedzinie. $\mathrm{Z}$ tego powodu ponownie umniejszono znaczenie tego problemu i dokonano decentralizacji w zarządzaniu grobownictwem wojennym, co poskutkowało oddzielnym wzorem postępowania i zróżnicowaniem postępów w jego uporządkowaniu w każdym województwie.

O mogiłach wojennych jednak nie zapomniano i na arenę ogólnopolską ich temat wrócił wraz z przygotowanym w MRP, a dopracowanym w MSW projektem ustawy o grobach i cmentarzach wojennych. Prace i międzyministerialne dyskusje nad nim toczyły się dość szybko i sprawnie, nie występowały tu punkty zapalne jak w przypadku ustawy o chowaniu zmarłych i stwierdzeniu przyczyny zgonu z 1932 r., gdzie ścierały się opinie, interesy i kompetencje państwa i Kościoła. Choć pierwotny wydźwięk ustawy miał być inny (przede wszystkim miał uregulować opiekę nad grobami żołnierzy polskich, a innych - pod warunkiem wzajemności), to wzorem przepisów traktatowych zrezygnowano z takiego rozróżnienia.

Także w parlamencie wszystkie frakcje były zgodne co do poparcia dla ustawy, gdyż projekt nie wywołał żadnej dyskusji ani w Sejmie, ani w Senacie. Świadczy to o konsensusie społecznym w kwestii potrzeby uregulowania kwestii 
grobownictwa wojennego i o braku kontrowersji związanych z samym tematem bądź rozwiązaniami przygotowanymi w ustawie. Niestety ze względu na niedostateczne środki finansowe duża liczba grobów i cmentarzy wojennych znajdujących się na terenie kraju do końca trwania II Rzeczypospolitej nie doczekała się należytej opieki. Do tego problem w zakresie nieuporządkowanych pojedynczych i zbiorowych mogił wojennych ogromnie wzrósł po II wojnie światowej. I choć także w okresie Polski Ludowej oraz w ostatnich latach wielu trudności z nimi związanych nie udało się przezwyciężyć, to sama ustawa okazała się nadzwyczaj trwała, gdyż po jednostkowych zmianach obowiązuje do dziś. Razem z uzupełniającą ją w pewnych kwestiach ustawą z dnia 31 stycznia 1959 r. o cmentarzach i chowaniu zmarłych nadal jest podstawowym aktem prawnym z zakresu ochrony i opieki nad grobami wojennymi ${ }^{98}$.

\author{
FROM THE WORK ON THE LEGAL REGULATION OF PROTECTION \\ AND CARE OVER THE WAR GRAVES IN THE SECOND POLISH REPUBLIC
}

Abstract

After World War I, the Polish-Bolshevik war and the local military conflicts, the reborn Polish state had to face the burning problem of a huge number of disorganised war graves scattered throughout the country. Poland was obliged to regulate the legal protection and care of such objects not only by unwritten humanitarian and civilization duties, but also by ratified international treaties. The aim of the article is to present the chronology and scope of works, entities responsible for them, as well as individual ideas and solutions for war graves used in the Second Republic.

K e y w o r d s: war graves, war cemeteries, Second Polish Republic

${ }^{98}$ M. Czyżak, Prawna ochrona grobów i cmentarzy wojennych w polskim systemie prawnym, „Wojskowy Przegląd Prawniczy” 2011 nr 2, s. 51; J. Mazurkiewicz, Niepożądani czerwonoarmiści, ignorowani niemieccy antyfaszyści i honorowani esesmani. O statusie prawnym i realiach grobów oraz cmentarzy wojennych radzieckich i niemieckich w Polsce, Wrocław 2016, s. 4-5. 